Article

\title{
High NDVI and Potential Canopy Photosynthesis of South American Subtropical Forests despite Seasonal Changes in Leaf Area Index and Air Temperature
}

Piedad M. Cristiano ${ }^{1, *}$, Nora Madanes ${ }^{1}$, Paula I. Campanello ${ }^{2}$, Débora di Francescantonio ${ }^{2}$, Sabrina A. Rodríguez ${ }^{1,2}$, Yong-Jiang Zhang ${ }^{4,5}$, Laureano Oliva Carrasco ${ }^{2}$ and Guillermo Goldstein ${ }^{1,3}$

1 Laboratorio de Ecología Funcional, Departamento de Ecología Genética y Evolución, Instituto IEGEBA (CONICET-UBA), Facultad de Ciencias Exactas y Naturales, Universidad de Buenos Aires, CABA, C1428EGA, Argentina;

E-Mails: noram@ege.fcen.uba.ar (N.M.); sabrinarodriguez78@yahoo.com.ar (S.A.R.); goldstein@bio.miami.edu (G.G.)

2 Laboratorio de Ecología Forestal y Ecofisiología, Instituto de Biología Subtropical-CONICET, FCF, Universidad Nacional de Misiones, Puerto Iguazú, Misiones, 3370, Argentina;

E-Mails: pcampanello@yahoo.com (P.I.C.); debo_difra@hotmail.com (D.F.); laureanoolivac@gmail.com (L.O.C.)

3 Department of Biology, University of Miami, Miami, FL 33124, USA

4 Department of Organismic and Evolutionary Biology, Harvard University, Cambridge, MA 02138, USA; E-Mail: yongjiangzhang@oeb.harvard.edu

5 Key Laboratory of Tropical Forest Ecology, Xishuangbanna Tropical Botanical Garden, Chinese Academy of Sciences, Mengla, Yunnan 666303, China

* Author to whom correspondence should be addressed; E-mail: piedad@ege.fcen.uba.ar; Tel.:+54-11-4576-3300 (ext. 415); Fax: +54-11- 4576-3354.

Received: 14 December 2013; in revised form: 16 February 2014 / Accepted: 17 February 2014 / Published: 20 February 2014

Abstract: The canopy photosynthesis and carbon balance of the subtropical forests are not well studied compared to temperate and tropical forest ecosystems. The main objective of this study was to assess the seasonal dynamics of Normalized Difference Vegetation Index (NDVI) and potential canopy photosynthesis in relation to seasonal changes in leaf area index (LAI), chlorophyll concentration, and air temperatures of NE Argentina subtropical forests throughout the year. We included in the analysis several tree plantations (Pinus, 
Eucalyptus and Araucaria species) that are known to have high productivity. Field studies in native forests and tree plantations were conducted; stem growth rates, LAI and leaf chlorophyll concentration were measured. MODIS satellite-derived LAI (1 km SIN Grid) and NDVI (250m SIN Grid) from February 2000 to 2012 were used as a proxy of seasonal dynamics of potential photosynthetic activity at the stand level. The remote sensing LAI of the subtropical forests decreased every year from 6 to 5 during the cold season, similar to field LAI measurements, when temperatures were $10{ }^{\circ} \mathrm{C}$ lower than during the summer. The yearly maximum NDVI values were observed during a few months in autumn and spring (March through May and November, respectively) because high and low air temperatures may have a small detrimental effect on photosynthetic activity during both the warm and the cold seasons. Leaf chlorophyll concentration was higher during the cold season than the warm season which may have a compensatory effect on the seasonal variation of the NDVI values. The NDVI of the subtropical forest stands remained high and fairly constant throughout the year (the intra-annual coefficient of variation was $1.9 \%$ ), and were comparable to the values of high-yield tree plantations. These results suggest that the humid subtropical forests in NE Argentina potentially could maintain high canopy photosynthetic activity throughout the year and thus this ecosystem may be a large carbon sink.

Key words: canopy photosynthesis; ecosystem processes; growth rate; leaf chlorophyll; NDVI; remote sensing

\section{Introduction}

Compared to tropical and temperate forests, the carbon balance of subtropical forests is not well studied. Trees in humid subtropical forests may maintain relatively high photosynthetic rates even during the cold periods owing to relatively mild seasonal low temperatures. This pattern was observed for some East Asian subtropical evergreen forests [1,2]. Leaf level results show that net $\mathrm{CO}_{2}$ assimilation in dominant evergreen species of an East Asian subtropical forest never dropped below $50 \%$ of their photosynthetic capacity $[3,4]$. At stand level, the forest sites had considerably high values of carbon sequestration, as respiratory losses declined strongly during the cold season [1]. High year-round carbon sequestration suggests that these subtropical forests are among the largest carbon-sinks across terrestrial ecosystems. Subtropical forests are widespread in SE Asia, northern Australia and Argentina and are facing severe threats imposed by the expansion of tree plantations and agricultural lands.

The subtropical forests in northeastern (NE) Argentina are the southern portion of the Atlantic Forest Biome extending along the Atlantic coast of Brazil and southeastern Paraguay. Just a few centuries ago the Atlantic Forest was the second most extensive forest ecosystem in the Neotropics after the Amazonian forests. However, unlike the Amazonian forests, about $93 \%$ of the original cover of the Atlantic Forest has been lost due to human activities. Only small fragments of the subtropical Atlantic Forest remain in Brazil and Paraguay [5], while the largest stands of these forests are in 
Argentina. Despite the fact that most of this biome has been lost, the remnants still have high biological diversity and endemism and are included among the 25 top biodiversity hotspots in the world [6]. During the last three decades, the area dedicated to tree plantations in Argentina has increased five-fold [7]. Many humid subtropical forests in NE Argentina have been replaced recently by high-yield tree plantations of Eucalyptus and Pinus.

The temperature effects on the carbon balance of these forests have not been studied. Air temperatures of the subtropical Atlantic forests in Argentina drop considerably during the winter season but seldom reach freezing levels. The number of days with temperatures below $0{ }^{\circ} \mathrm{C}$ ranges from 0 to 12 per year [8]. If these subtropical forests maintain high canopy photosynthesis throughout the year despite low temperatures during the cold season, they can have a high capacity for yearly carbon sequestration. Thus conservation and restoration of subtropical forests worldwide are of importance for the global carbon cycle.

In recent decades, information provided by remote sensing has emerged as a new and useful tool to study the spatial and temporal dynamics of vegetation [9-12]. Passive sensors provide information on the percentage of energy from the sun that is reflected by different land covers in different wavelengths of the electromagnetic spectrum. In the case of the vegetation, this information is usually summarized by spectral indices to assess traits related to the structure and function of terrestrial ecosystems. The normalized vegetation index (NDVI) is one of the most used spectral indices because it is closely related to the amount of photosynthetically active radiation intercepted by vegetation, and the amount of green biomass and chlorophyll content in leaves [13-17]. This spectral index may provide valuable information on the temporal dynamics of photosynthetic activity and primary productivity $[12,18,19]$. Remote sensing is also used to estimate canopy leaf area index (LAI, the total leaf area per unit ground area). This variable is a controlling biophysical property of vegetation functioning, and quantifying LAI is thus of importance for understanding energy, carbon and water fluxes between the land surface and the atmosphere [20,21].

The main objective of this study was to assess the seasonal dynamics of NDVI and potential canopy photosynthetic activity in relation to seasonal changes in leaf area index (LAI), chlorophyll content, and air temperatures of NE Argentina subtropical forests, using remote sensing and field measurements. We also included, for comparative purposes, several plantations of Pinus, Eucalyptus and Araucaria that are known to have high yields and exhibit rather constant growth rates. Remote sensing was used to assess the seasonal dynamics of leaf pigments involved in carbon assimilation and total stand level gas exchange surface, and thus the spectral index used was considered to be a proxy of canopy photosynthetic activity. Stem growth rates, LAI and leaf chlorophyll concentration were monitored for the native forests and plantations. The subtropical forest studied is characterized by the coexistence of deciduous species with rapid growth rates and evergreen species with slower growth rates. The deciduous species are leafless during the mild winter season and thus the evergreen trees can use the relatively high incoming solar radiation when climatic conditions are more favorable for growth (temperatures closer to the optimum for $\mathrm{CO}_{2}$ assimilation). It was hypothesized that the NDVI values of humid subtropical forests in Argentina, as a measure of potential canopy photosynthetic activity, remains at high levels throughout the year, comparable to high-yield tree plantations. 


\section{Methods}

\subsection{Study Area}

Native species from the Atlantic Forest within the Iguazú National Park of Misiones Province, NE Argentina $\left(26^{\circ} 25^{\prime} \mathrm{S}, 54^{\circ} 37^{\prime} \mathrm{W}\right)$, and plantations of Pinus taeda, Pinus caribaea caribaea, a hybrid Pinus, Eucalyptus grandis and Araucaria angustifolia were monitored in this study. Mean annual rainfall in the area is $2000 \mathrm{~mm}$ and precipitation is evenly distributed throughout the year. Although there is not a dry season, some climatic anomalies can occur in some years such as a decrease in precipitation during few consecutive weeks triggering short-term drought effects. Mean annual temperature is $21^{\circ} \mathrm{C}$, with monthly means of $25^{\circ} \mathrm{C}$ in January and $15{ }^{\circ} \mathrm{C}$ in July, representing the warmest and coldest months of the year, respectively. The soils are derived from basaltic rocks, containing high concentration of $\mathrm{Fe}, \mathrm{Al}$ and $\mathrm{Si}$ and correspond to the 9a type according to local descriptions [22], which are mostly ultisols [23].

\subsection{Field Measurements}

Leaf Area Index (LAI), leaf chlorophyll concentration and stem growth were monitored in stands of the native forests and four tree plantations (Eucalyptus grandis, Araucaria angustifolia, Pinus taeda and Pinus caribaea caribaea). Measurements were done in March and July 2013, corresponding to late summer-early autumn and winter seasons, respectively.

Leaf area index (LAI) was calculated by a nondestructive method by measuring incoming light below the canopy and in an open area with the AccuPAR Lp-80 ceptometer (Decagon Devices, Pullman, WA, USA) at ten points randomly selected in each tree plantation and thirty points in the native forest stand. The Chlorophyll Meter SPAD 502 meter (Minolta, Japan) was used to estimate leaf chlorophyll concentration [24,25]. Three individuals were used in each of the tree plantations while in the native forests one tree of five different species was used: Balfourodendron riedelianum, Cedrela fissilis, Ceiba speciosa, Cordia trichotoma and Chrysophyllum gonocarpum (Table 1). Values of SPAD units obtained from 30 leaves of each species were converted to chlorophyll concentration in $\mu \mathrm{g} \mathrm{cm}^{-2}$ using the equation of Pinkard et al. [24] for E. grandis and Coste et al. [25] for the remaining species. Chlorophyll concentration and LAI measurements were done at the same time.

Ten species were selected and ten individuals per species were used to measure stem radial growth in the native forests and in the tree plantations. Dendrometer bands were installed on all selected trees. Dendrometers were made manually and consisted of a stainless steel tape encircling a tree stem, with one end passing through a collar (which is attached to the other end) and connected back to itself with a stainless steel spring, as described by Cattelino et al. [26]. Three months after dendrometer installation (allowing for stem-dendrometer adjustment) a permanent mark was made on the metal band next to the collar. As stem circumference increases, the mark moves away from the collar and the spring is stretched, keeping the dendrometer tight. A flexible ruler was used to measure stem circumference changes with an accuracy of $0.5 \mathrm{~mm}$. Stem circumference was recorded monthly from February 2012 to March 2013. Stem diameter increments were used as a proxy of stem growth and it was expressed as change in stem diameter with respect to the initial value at the beginning of the measurements. 
Table 1. List of tree species studied, their family, native or exotic origin, and leaf phenology.

\begin{tabular}{cccc}
\hline Family & Species & Origin & Phenology \\
\hline Rutaceae & Balfourodendron riedelianum (Engl.) Engl. & Native & Brevideciduous \\
Meliaceae & Cabralea canjerana (Vell.) Mart. & Native & Evergreen \\
Meliaceae & Cedrela fissilis Vell. & Native & Deciduous \\
Bombacaceae & Ceiba speciosa (A.St.-Hil., A.Juss. \& Cambess.) Ravenna & Native & Deciduous \\
Boraginaceae & Cordia trichotoma (Vell.) Arráb. ex Steud. & Native & Deciduous \\
Fabaceae & Holocalyx balansae Micheli & Native & Evergreen \\
Lauraceae & Ocotea diospyrifolia (Meisn.) Mez. & Native & Evergreen \\
Fabaceae & Lonchocarpus muehlbergianus Hassl. & Native & Brevideciduous \\
Fabaceae & Parapiptadenia rigida (Benth.)Brenan & Native & Brevideciduous \\
Sapotaceae & Chrysophyllum gonocarpum (Mart. \& Eichler) Engl. & Native & Evergreen \\
Araucariaceae & Araucaria angustifolia (Bertol.) Kuntze & Native & Evergreen \\
Myrtaceae & Eucalyptus grandis W.Hill ex Maiden & Exotic & Evergreen \\
Pinaceae & Pinus elliotti elliotti $\times$ P. caribaea hondurensis (hybrid Pinus) & Exotic & Evergreen \\
Pinaceae & Pinus taeda L. & Exotic & Evergreen \\
\hline
\end{tabular}

\subsection{Remote Sensing and Meteorological Variables}

The Terra MODIS sensor (Moderate Resolution Imaging Spectroradiometer) is a 36-band spectroradiometer that measures visible and infrared radiation from 0.4 to $14.5 \mu \mathrm{m}$. The individual spectral bands have different spatial and temporal resolutions. The measurements made by the MODIS sensor yield data used to develop different products, e.g. vegetation indices, productivity estimates, land surface cover, fire occurrence [27]. The different spatial and temporal resolutions depend on the product. Two products of satellite images of Terra-MODIS sensor (MOD13Q1 and MOD15A2) were used to analyze the Normalized Difference Vegetation Index (NDVI) and Leaf Area Index (LAI), respectively, during a period of 14 years (2000-2013). The MOD13Q1 is a vegetation index product that uses information of blue, red, and near-infrared reflectance (centered at 469, 645 and $858 \mathrm{~nm}$, respectively) to determine two daily vegetation indices, one of which is the NDVI, used in this study. The basis of this product is formed by atmospherically corrected bi-directional surface reflectance with masking for water, clouds, heavy aerosols, and cloud shadows. This product represents a 16-day composite (temporal resolution) at 250 meter spatial resolution in a sinusoidal projection. This particular composite allows the algorithm to include only values that are acquired during cloud-free days and/or days when the data is considered more reliable due to the absence of water, clouds, and heavy aerosols in the atmosphere [28]. The MODIS land product MOD15A2 provides global time series of Leaf Area Index (LAI)-Fraction of Photosynthetically Active Radiation (FPAR). Data is provided with a $1 \mathrm{~km}$ and 8 -day spatial and temporal resolution, respectively. In this study we extracted and used only the LAI information. The main algorithm of this MODIS product is based on a lookup table which is generated using a $3 \mathrm{D}$ radiative transfer model. A structural biome map is used for defining the expected range of vegetation structure and soil patterns when modeling the bi-directional reflectance factors (BRFs). Modeled and observed BRFs are compared and those solutions are accepted where the residuals are smaller than biome-related levels of model and 
observation uncertainty. Finally, the average LAI of all accepted solutions is calculated. The algorithm accounts for clumping at leaf, canopy and partly at landscape scale. In case the main algorithm fails, a backup method is used. This backup method relies on biome-specific relationships between vegetation indices and LAI [29]. For further details on the MODIS LAI algorithm, see Myneny et al. [30] and Jacquemoud et al. [31]. The images of both products were obtained from the Land Processes Distributed Active Archive Center website [32]. The MOD13Q1 and MOD15A2 are projected on a sinusoidal $10^{\circ}$ grid, where the globe is divided for production and distribution purposes into 36 tiles along the east-west axis, and 18 tiles along the north-south axis each approximately of $10 \times 10$ degrees [30]. In this study, the h13v11 tile was used. NDVI and LAI values were averaged monthly.

Using Google Earth, homogeneous continuous areas of over 100 hectares (in order to use the MODIS LAI product) were selected for native forest stands $(n=3)$ and tree plantations: P. taeda $(n=2)$ and E. grandis $(n=2)$. Only one plantation of $A$. angustifolia was found with an area larger than 100 ha (Table 2). Even though MODIS LAI data were obtained, the results were not included in tables and figures containing stand level information because of lack of replications. The vegetation in the study area is fragmented with remnants of native forests and tree plantations. Most of the plantations have areas that are smaller than 1 pixel, not large enough to use the MODIS Terra LAI product that requires $1 \mathrm{~km}^{2}$ size pixel. For example, we were not able to find an area larger than 10 ha for the hybrid pine. All sites were inspected in the field and those sites with pixels containing at least $85 \%$ of the target vegetation/tree plantations coverage were selected. The number of pixels used to characterize LAI and the geographical coordinates of the center of each site is included in Table 1 . The sites selected had the same soil type [9,20] and topography (200-300 m asl). Monthly precipitation, average mean, maximum, minimum temperature and global radiation from the nearest meteorological station (Puerto Iguazú-Aero, Servicio Meteorológico Nacional, Argentina, 254ㄴ $48^{\prime \prime}$ S; -54²8'11.99" W) were used to characterize climatic conditions at the study sites.

Table 2. Central geographic coordinate and number of pixels used to characterize NDVI (Normalized Difference Vegetation Index) and LAI (Leaf Area Index) in each study site from the MODIS-Terra product.

\begin{tabular}{ccccc}
\hline Study sites & Latitude (S) & Longitude (W) & $\begin{array}{c}\text { NDVI } \\
\mathbf{N}^{\circ} \text { pixels }\end{array}$ & $\begin{array}{c}\text { LAI } \\
\mathbf{N}^{\circ} \text { pixels }\end{array}$ \\
\hline Native forest & $25^{\circ} 41^{\prime} 28.51^{\prime \prime}$ & $54^{\circ} 29^{\prime} 9.59^{\prime \prime}$ & 26 & 1 \\
& $25^{\circ} 44^{\prime} 30.78^{\prime \prime}$ & $54^{\circ} 21^{\prime} 39.17^{\prime \prime}$ & 56 & 3 \\
& $25^{\circ} 48^{\prime} 16.13^{\prime \prime}$ & $54^{\circ} 15^{\prime} 6.77^{\prime \prime}$ & 14 & 2 \\
\hline \multirow{2}{*}{. taeda } & $26^{\circ} 9^{\prime} 50.20^{\prime \prime}$ & $54^{\circ} 26^{\prime} 50.08^{\prime \prime}$ & 42 & 2 \\
& $25^{\circ} 47^{\prime} 54.14^{\prime \prime}$ & $54^{\circ} 25^{\prime} 11.57^{\prime \prime}$ & 63 & 2 \\
\hline \multirow{2}{*}{. grandis } & $26^{\circ} 6^{\prime} 34.80^{\prime \prime}$ & $54^{\circ} 26^{\prime} 10.68^{\prime \prime}$ & 10 & 2 \\
& $26^{\circ} 7^{\prime} 43.13^{\prime \prime}$ & $54^{\circ} 34^{\prime} 33.16^{\prime \prime}$ & 9 & 1 \\
\hline A. angustifolia & $26^{\circ} 14^{\prime} 48.92^{\prime \prime}$ & $54^{\circ} 30^{\prime} 38.73^{\prime \prime}$ & 12 & 1 \\
\hline
\end{tabular}




\subsection{Data Analysis}

The temporal analysis of the changes in vegetation function was based in the NDVI spectral metric. Three variables were used to characterize potential functional changes in photosynthetic activity: mean annual NDVI, intra-annual and inter-annual coefficients of variation of the NDVI in native forests and tree plantations. The same procedure was used with the LAI from remote sensing data for temporal analysis of structural changes in the vegetation. Ninety-five percent confidence intervals were obtained for averaged NDVI in order to assess statistical differences between vegetation types. Regression analysis of NDVI versus monthly stem growth rates and monthly temperatures were performed. The NDVI and LAI values from remote sensing were analyzed through Single Spectrum (Fourier) Analysis to detect cyclical patterns in the time series. This statistical procedure allows decomposing a complex time series, with cyclical components into a few underlying sine and cosine function of particular wavelengths. Thus it is possible to reveal a few recurring cycles of different length interval in the time series of interest [33-35]. The periodogram values can be interpreted in terms of the variance explained by a particular frequency (or its inverse: the time at which the recurring cycles is observed e.g., every six months, because the unit of time in this study is a month). Similar time series analysis was performed on average air temperature to assess if the periodicity of this meteorological variable corresponds to recurring cycles in the NDVI series. Differences in field LAI and chlorophyll concentration among native forests and plantations were analyzed by a two-way ANOVA test with simple effects, after assumptions of normality and homoscedasticity were assessed. The two factors were vegetation type (native forest and four tree plantations) and time (March and July).

\section{Results and Discussion}

\subsection{Results}

Solar radiation decreases two-fold during the cold season because of the relatively low sun angle and shorter days (Figure 1a). Precipitations exhibit month-to-month differences, but there is no clear seasonal pattern of variations (Figure 1b). Air temperatures are about $10{ }^{\circ} \mathrm{C}$ lower during the cold season than for the warmest season. Subzero daily temperatures are very unlikely during the short winter period (Figure 1c). Average monthly temperatures are very high from December through February.

NDVI values remained within the 0.8 to 0.9 range for the native forests, E. grandis and A. angustifolia stands (Figure 2a). The two P. taeda plantations were planted in 2003 and 2006 with NDVI increasing until reaching the highest values in 2011 (Figure 2b). The insets in Figure 2 show average monthly NDVI. The NDVI of the native forests tended to be $5 \%$ higher compared to the NDVI of the plantations as indicated by the $95 \%$ confidence intervals. The lowest values were observed in August and September and the highest in March, April and November for the native forests. The NDVI values across most of the ecosystem types tended to decrease during the months with the highest air temperatures (December, January and February); however, the magnitude of the drop was not as large as it was during the cold season.

The intra-annual variations of NDVI were very small and similar among the study sites. In the native forests, the NDVI values decreased an average of $1.9 \%$ between the warm and the cold season 
(Table 3). The seasonal decreases in NDVI were similar for E. grandis, P. taeda and A. angustifolia plantations (mean values of 2.2\%, 2.0\% and 2.2\%, respectively) (Table 3). The inter-annual variations of NDVI were smallest in native forests (mean value of $0.86 \%$ ) compared with the tree plantations. Within tree plantations, P. taeda exhibited the largest NDVI variation among years (Table 3 ).

The seasonal variation of MODIS LAI ranged from 4 to 6.8 depending on the ecosystem studied (Figure 3). The LAI values were lowest during the cold season and highest during March, April and November across ecosystem types (Figure 3 insets). The intra-annual variations of LAI were similar among the study sites although the $A$. angustifolia plantation exhibited twice as much variation among years $(14.4 \%)$ compared to other study sites. The inter-annual variations of LAI ranged between $2.8 \%$ and $13.7 \%$ (Table 3 ).

Figure 1. Seasonal variations of (a) monthly global radiation, (b) monthly total precipitation, and (c) monthly air temperatures obtained from daily mean temperatures from 2000 until 2012 (Puerto Iguazú-Aero Meteorological Station, Argentina).

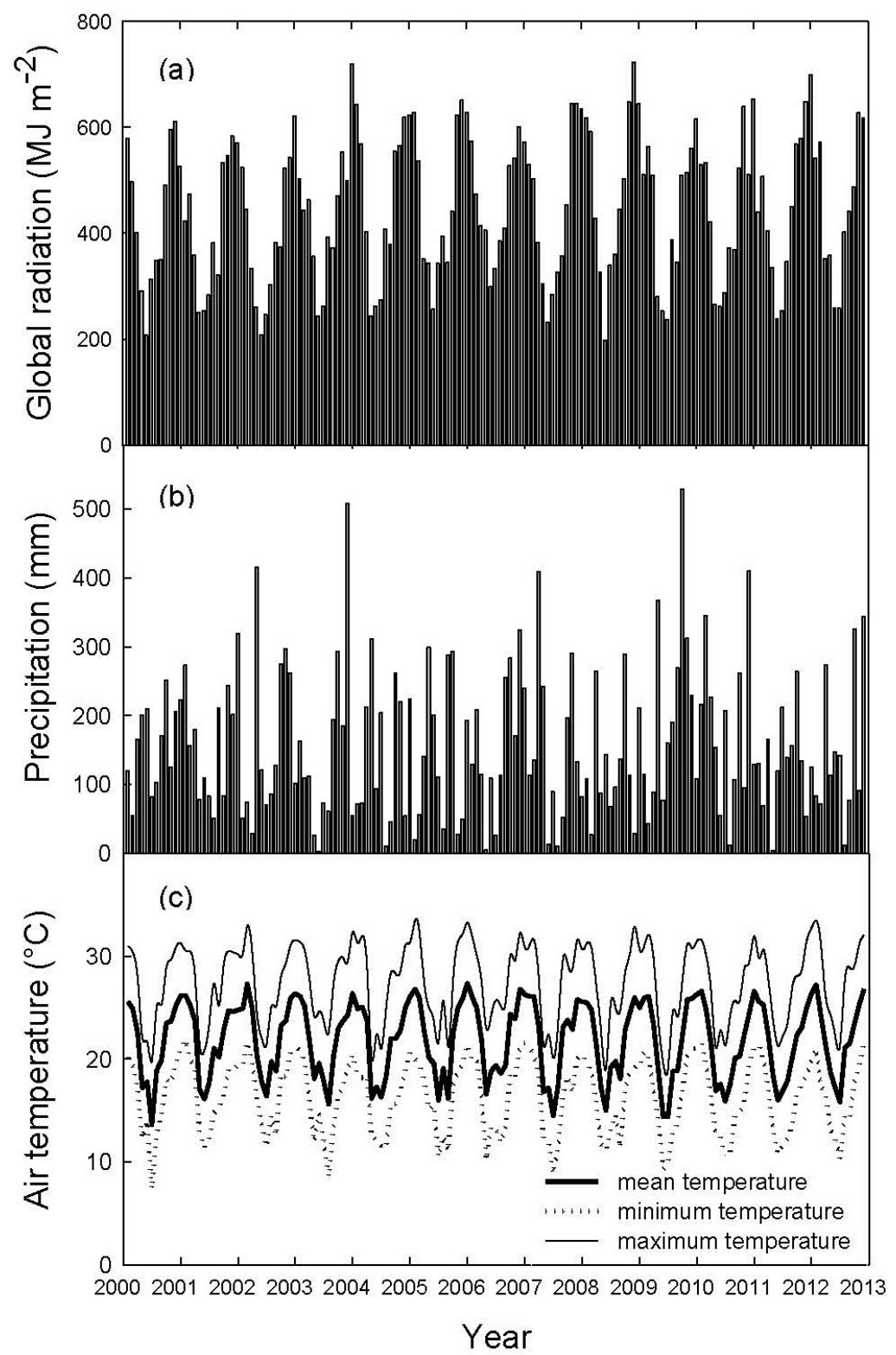


Figure 2. Monthly MODIS NDVI from 2000 to 2013 of (a) a native forest and tree plantations of Eucalyptus grandis and Araucaria angustifolia and (b) a native forest compared with two tree plantations of Pinus taeda planted in different years. Inset: annual dynamic of NDVI obtained from the monthly averages of the: 2000 to 2013 time series for the native forest, 2000 to 2012 for E. grandis and A. angustifolia, and for 2009 to 2013 for both $P$. taeda species. Numbers 1 through 12 in the $X$-axis insets correspond to January through December. Bars indicate the $95 \%$ confidence intervals. Arrow indicates the time when $E$. grandis plantation was harvested.

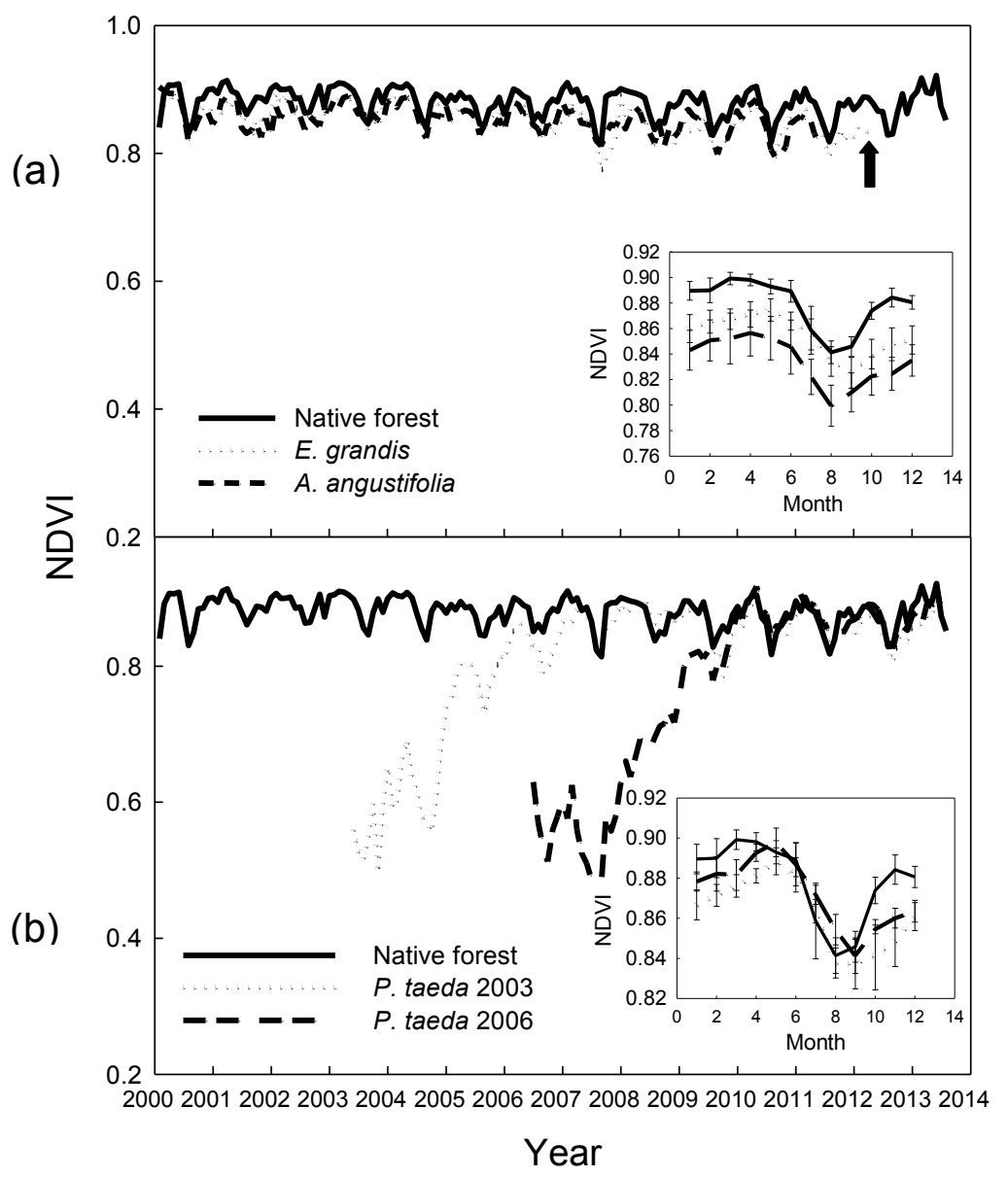

Table 3. Mean annual NDVI (Normalized Difference Vegetation Index) and LAI (Leaf Area Index) values obtained from remote sensing and their intra-annual and inter-annual coefficients of variation (CV, \%) for three native forest stands and two Eucalyptus grandis, two Pinus taeda and one Araucaria angustifolia tree plantations.

\begin{tabular}{cccccccccc}
\hline \multirow{2}{*}{ Study sites } & \multicolumn{3}{c}{ Native forests } & \multicolumn{2}{c}{ E. grandis } & A. angustifolia & \multicolumn{2}{c}{ P. taeda } \\
\cline { 2 - 9 } & $\mathbf{1}$ & $\mathbf{2}$ & $\mathbf{3}$ & $\mathbf{1}$ & $\mathbf{2}$ & $\mathbf{1}$ & $\mathbf{1}$ & $\mathbf{2}$ \\
\hline Mean NDVI & 0.88 & 0.88 & 0.89 & 0.85 & 0.87 & 0.83 & 0.86 & 0.87 \\
Intra-annual CV & 2.2 & 2.0 & 1.6 & 1.8 & 2.6 & 2.2 & 2.1 & 2.0 \\
Inter-annual CV & 0.8 & 0.9 & 0.9 & 2.9 & 7.3 & 4.5 & 14.6 & 13.6 \\
\hline Mean LAI & 5.59 & 5.58 & 5.60 & 5.67 & 5.62 & 5.21 & 5.96 & 6.09 \\
Intra-annual CV & 6.5 & 5.8 & 5.8 & 9.0 & 6.4 & 14.4 & 6.0 & 4.7 \\
Inter-annual CV & 4.9 & 3.8 & 3.3 & 2.9 & 13.7 & 6.5 & 3.6 & 2.8 \\
\hline
\end{tabular}


Figure 3. Monthly MODIS LAI (Leaf Area Index) from 2000 to 2013 of (a) a native forest and Eucalyptus grandis and (b) two tree plantations of Pinus taeda planted in different years. The black arrow in panel (a) indicates the time when the A. angustifolia and E. grandis plantations were cleared. Inset: annual dynamic of LAI obtained from the monthly averages of the: 2000 to 2013 time series for the native forest, 2000 to 2012 for E. grandis, and for 2009 to 2013 for both $P$. taeda species. Numbers 1 through 12 in the $X$-axis insets correspond to January through December.

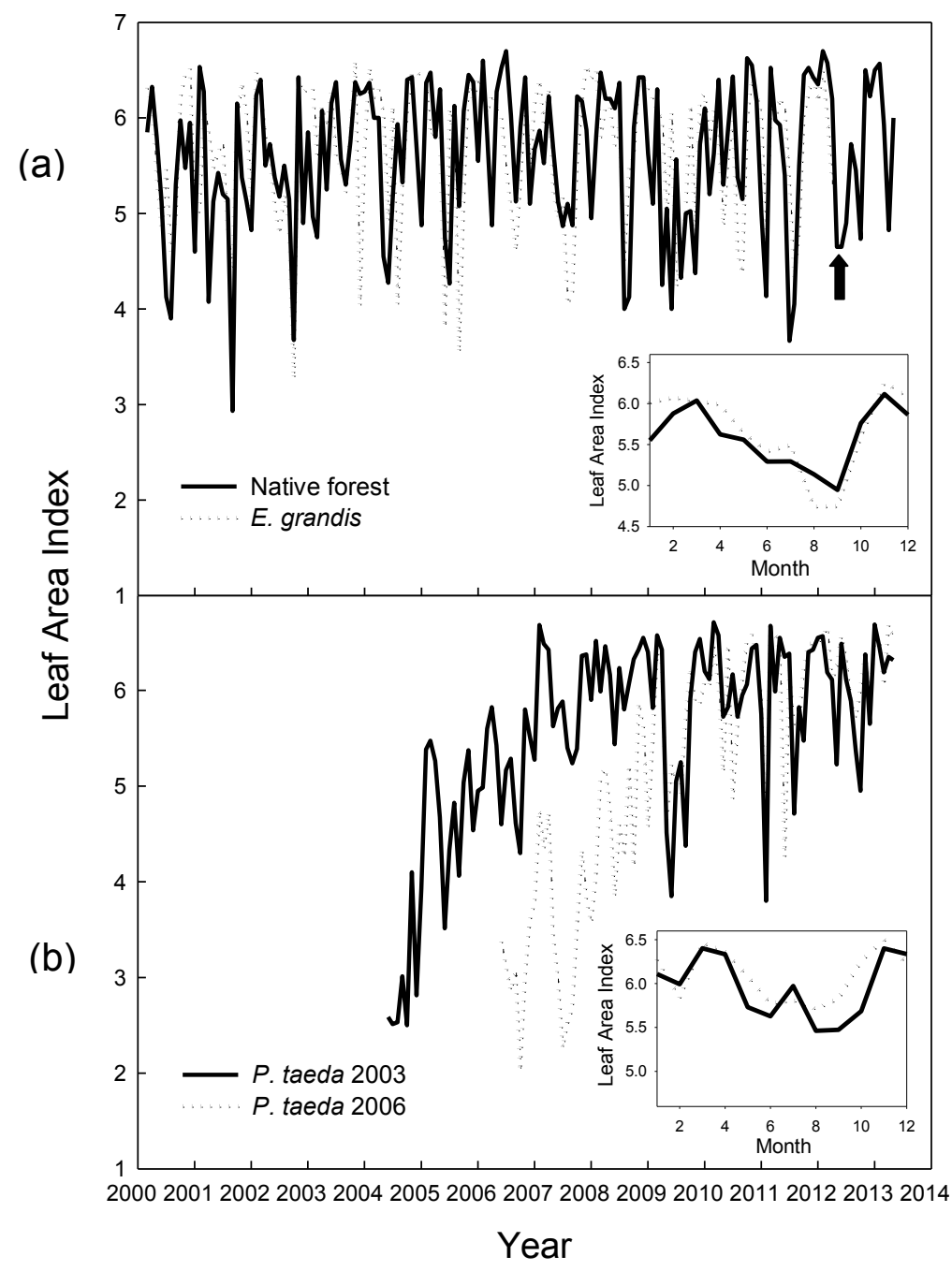

The time series analysis from 2000 to 2012 of NDVI monthly values for the native forest showed a main frequency component of 0.082 cycles per sampling interval, corresponding to a 12 -month period, and a secondary component of 0.166 cycles per sampling interval, corresponding to a 6 -month period (Figure 4a). Other significant components were not observed (Table 4). The periodogram of LAI values for the same time period exhibited more peaks; however, there were only three significant peaks corresponding to 12-, 7.2- and 4-month periods (Figure $4 \mathrm{~b}$ and Table 4). A time series analysis with temperature data was also performed (inset of Figure 4a). Consistent with the results of NDVI, nearly all the variance of the time series was explained by a 12-month period. 
Figure 4. (a) NDVI (Normalized Difference Vegetation Index) and (b) LAI (Leaf Area Index) peridograms for the native forests. The Y-axes are the percent of variance explained at each frequency, the inverse of the time periods in months. In the inset, the periodogram of average monthly temperatures for a 12 -year period is shown.

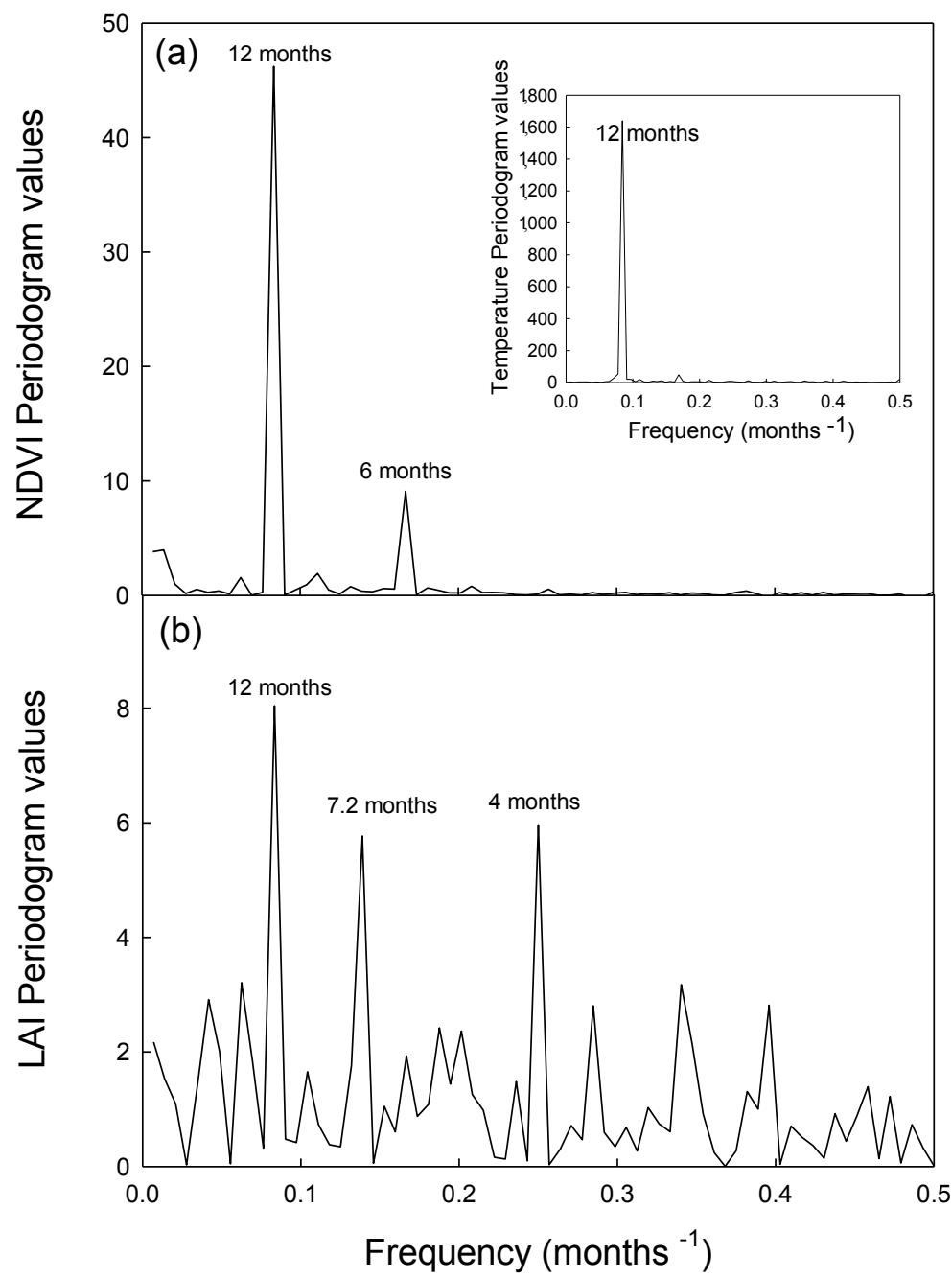

Leaf chlorophyll concentration tended to be higher during the cold season (July) compared with the warm season, but the differences were significant for the native forests and the hybrid Pinus only (Figure 5a). In the native forests, leaf chlorophyll concentration was higher for the evergreen than for the deciduous species when both functional groups had active leaves. Across ecosystem types (native forests and tree plantation) leaf chlorophyll concentration was significantly higher for $\mathrm{A}$. angustifolia for both March $(\mathrm{F}=58.61, \mathrm{df}=4, p<0.05)$ and July $(\mathrm{F}=76.64, \mathrm{df}=4, p<0.05)$ compared to other ecosystems. Field LAI ranged from 7.5 to 4 , similar in range to satellite estimates. LAI tended to be lower in July than in March, particularly for the native forest, likely the result of the leaf drop of deciduous species (Figure 5b, Table 1). Across ecosystem types, LAI values in March of the native forest and $A$. angustifolia stands were significantly higher than for E. grandis and both Pinus tree plantations $(\mathrm{F}=67.93$, df $=4, p<0.05)$. In July, LAI values of $A$. angustifolia were significantly higher than all other ecosystems types, and the LAI for native forests was higher than for E. grandis tree plantations $(\mathrm{F}=17.02, \mathrm{df}=4, p<0.05)$. 
Table 4. Parameters of the time series analysis of the NDVI (Normalized Difference Vegetation Index) and LAI (Leaf Area Index) values obtained from remote sensing for native forest stands and Eucalyptus grandis, Pinus taeda and Araucaria angustifolia tree plantations. The period (in months) is the length of the recurring time cycles that explained the two largest amount of variance (Var. explained) in the time series. The initial and ending dates of the time series are also included.

\begin{tabular}{|c|c|c|c|c|c|c|c|c|}
\hline \multirow[t]{2}{*}{ Study Sites } & \multicolumn{2}{|c|}{ Native Forests } & \multicolumn{2}{|c|}{ E. grandis } & \multicolumn{2}{|c|}{ P. taeda } & \multicolumn{2}{|c|}{ A. angustifolia } \\
\hline & NDVI & LAI & NDVI & LAI & NDVI & LAI & NDVI & LAI \\
\hline Initial date & 1 January & 1 January & 1 January & 1 January & 7 January & 7 July & 1 January & 1 January \\
\hline Ending date & 12 December & 12 December & 11 December & 11 December & 12 December & 12 December & 11 December & 11 December \\
\hline Period & 12 & 12 & 12 & 12 & 12 & 12 & 12 & 12 \\
\hline Var. Explained & 46.2 & 8.0 & 37.7 & 20.8 & 49.31 & 5.86 & 50.8 & 26.2 \\
\hline Period & 6 & 4 & 132 & 6 & 72 & 10 and 7 & 120 & 11 \\
\hline Var. Explained & 9.1 & 6.0 & 29.4 & 5.0 & 6.6 & 3.6 & 14.7 & 14.4 \\
\hline
\end{tabular}


Figure 5. Field measurements of (a) chlorophyll content and (b) Leaf Area Index for two months: March (black bars) and July (grey bars), corresponding to summer and cold seasons, respectively. Bars are means + SE. In tree plantations $n=3$ for chlorophyll content and $n=10$ for LAI. In the native forest stands $n=5$ for chlorophyll content and $n=30$ for LAI. * Indicates significant differences between times (March and July) within each ecosystem type at $p<0.05$.

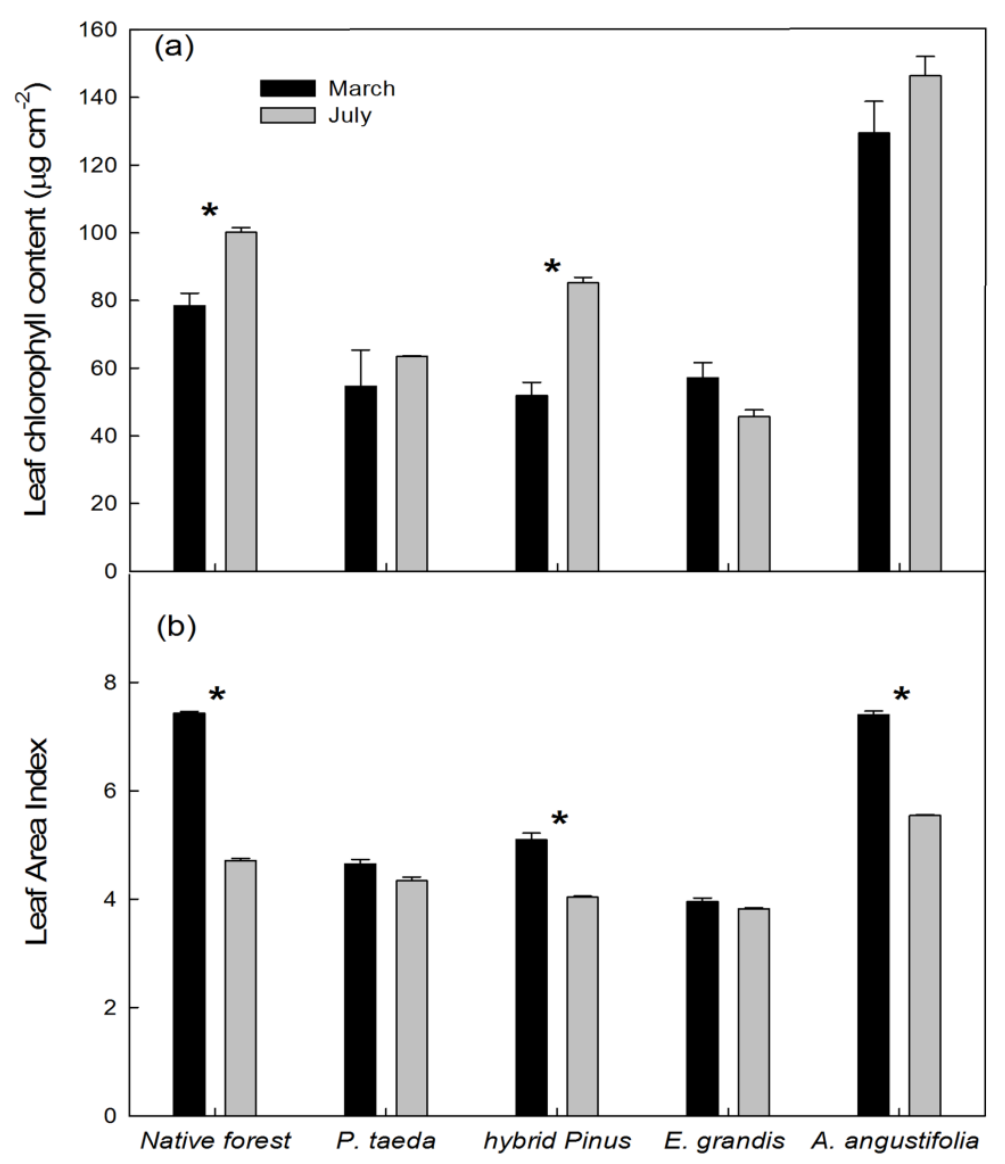

The relative growth rates were higher for the relatively younger Pinus and Eucalyptus plantations than for the native forests (Figure 6). The A. angustifolia plantation had intermediate growth rates between the young tree plantations and the native forests. Araucaria angustifolia is a native tree that is used in plantations in NE Argentina, and the stand measured in this study was about 30 years old. In native forests, the deciduous species have relatively higher growth rates than the evergreen species within the same forest stand. The slope of the cumulative growth versus time indicates the magnitude of the growth rate. The slopes were lower (lower growth rates) during the cold season (June through August) and were higher during the warmer months (December through March) across all tree plantations (Figure 6). The growth rates increased substantially after October for the deciduous and evergreen species in the native forest stands. A significant positive linear relationship between monthly stem growth increments and NDVI for either evergreen $(p<0.05)$ or deciduous species $(p<0.01$ was observed). However growth rate as an independent variable only explained $42 \%$ and $47 \%$ of the variation in monthly NDVI (inset in Figure 6). 
Figure 6. Cumulative stem diameter changes (percentage growth normalized to the initial stem diameter) for deciduous and evergreen trees in the native forest and four tree plantations from February 2012 to March 2013. Vertical bars in March 2013 indicate the SE. The inset indicates the significant relationship $(p<0.05)$ between NDVI and the cumulative stem growth of native evergreen species (black circles and solid line, $R^{2}=0.42$ ) and the native deciduous species (white circles and dash-dot line, $R^{2}=0.47$ ).

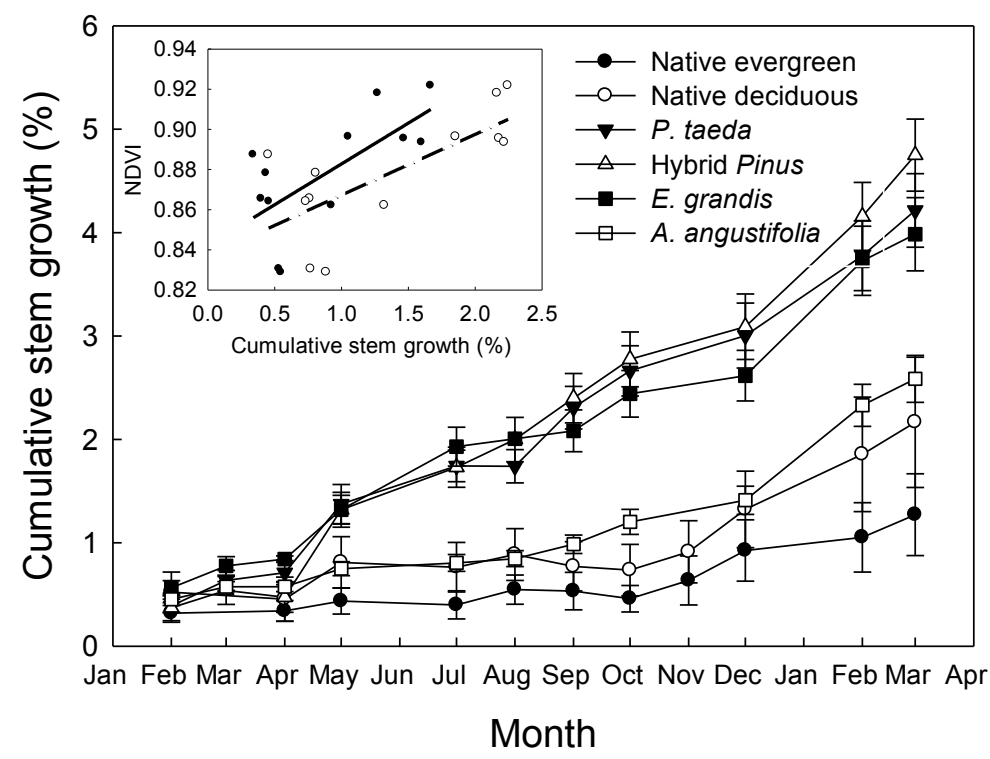

\subsection{Discussion}

\subsubsection{Seasonal Variation in NDVI and Potential Canopy Photosynthesis}

High NDVI values of the Atlantic subtropical forests throughout the year were observed in this study. The seasonal changes in NDVI were relatively small compared to seasonal changes in LAI and air temperatures. The NDVI, measuring visible and infrared radiation of the upper canopy forests, can provide an estimate of the average potential integrated photosynthetic activity of the tallest tree layers of the forest $[12,20,21,36]$. Although canopy gas exchanges were not directly measured in the present study, it is reasonable to expect a link between NDVI (as a proxy for leaf chlorophyll content and total leaf surface area) and canopy photosynthetic rates. Other evidences obtained with field measurements such as LAI, leaf chlorophyll concentration and stem growth rates suggest that carbon assimilation at stand level is probably high and fairly constant throughout the year. Furthermore, comparison with high-yield plantations resulting in similar seasonal NDVI patterns reinforces the hypothesis that subtropical forests have high potential canopy photosynthesis. It has been suggested that NDVI is less sensitive at high LAI values (e.g., [37]), and other vegetation indices have been developed to assess canopy photosynthetic performance of different vegetation types with relative high LAI such as the enhanced vegetation index (EVI). The dynamics of the canopy photosynthetic activity in the different study sites was also analyzed by the EVI but no differences were found between this spectral index and NDVI. We used NDVI to facilitate comparison with other ecosystems since it is the most widely used vegetation index [13-16]. The cold season decline in NDVI suggests a depression in canopy photosynthesis, which is related to the direct low temperature effects on leaf photosynthetic enzyme 
activities [38] and the seasonal decrease in photosynthetic leaf surface area due to a LAI decrease. However, the NDVI values remained considerably high even during the cold season $(>0.8)$, suggesting that the studied subtropical forests were potentially able to maintain high canopy photosynthesis even during the coldest months. This could be the results of high leaf chlorophyll concentrations and low respiration rates in the cold season. Another plausible explanation of the bi-annual dip in NDVI is the existence of various components of the forest community with different phenological patterns and physiological responses. The evidences we have obtained from this and previous studies $[2,3,39]$ lead us to assume that the seasonal variations in potential canopy photosynthesis is not only the result of different phenological and physiological behaviors but also caused by temperature effects on carbon assimilation and by seasonal changes in stand level LAI. Photosynthetic performance (light-saturated net $\mathrm{CO}_{2}$ assimilation was monitored using a portable photosynthesis system) of 10 tree species in subtropical forests of China downregulated maximum photosynthesis during winter by only $13 \%$ to $53 \%$ and thus the trees were able to maintain considerably high winter carbon assimilation during this period [4]. In these forests, NDVI ranged from 0.7 to 0.8 , depending on the season [40]. These subtropical forests have a lower LAI and occur at a higher elevation than the subtropical forests studied in NE Argentina. The results from Argentinean subtropical forests therefore agree with the studies in Asian subtropical forests supporting the statement that subtropical forests could be large carbon sinks owing to year-round carbon sequestration [1-4].

The NDVI values of the studied forests in NE Argentina ranged from 0.8 to 0.9 , close to 1 that represents the maximum NDVI for a given terrestrial ecosystem. The values of NDVI were lower in very young forest plantations; however, when a full canopy was attained, the NDVI values reached the 0.8 to 0.9 range. The NDVI values and yearly patterns were rather similar between native forests and plantations that have reached complete canopy cover, though the NDVI of the native forest was consistently $5 \%$ higher compared to the NDVI of the plantations. The NDVI values of the studied forests were higher than the average values of other forest ecosystems. For example, for a semideciduous forest in central Brazil, NDVI ranges from 0.5 and 0.9 and decreases seasonally by $25 \%$, while deciduous forests in the same region ranged from 0.3 to 0.9 and decreased $50 \%$ during the dry season [12]. NDVI values in temperate beech forests ranged from 0.4 to 0.9 , and the NDVI values in temperate oak forests ranged from 0.3 to 0.9 , while that of temperate pine forests were maintained relatively constant at a value of about 0.65 [41].

The time series analysis of NDVI values at stand level for the native forest showed two recurring cycles at 12 and 6 months in the time series. The main 12-month cycle represents the decrease in NDVI during the cold season that occurs once every year. Even though the decrease was only $2 \%$ from the maximum, it was a recurrent decrease during each cold season from 2000 until 2012. The secondary cycle at 6 months corresponds to the two NDVI peaks in autumn (March and April) and spring (November) (inset Figure 2a). This implies that December, January and February had relatively low NDVI values corresponding to the months with the highest air temperatures. During this period, lower chlorophyll concentrations (Figure 5a) and potentially the partial inhibition of the photosynthetic apparatus due to very high temperatures and higher PPFDs may have resulted in relatively low NDVI values. This seasonal pattern in potential canopy photosynthesis suggested by remote sensing should be further confirmed by leaf level and forest level carbon exchange measurements. A time series analysis with temperature data was consistent with the results of NDVI because nearly all the variance 
of the time series was explained by a 12-month period providing further evidences that seasonal variation in air temperature is partially driving temporal trends in NDVI.

The decrease in NDVI from December to February (the hottest months) suggests that photosynthesis is very sensitive to high temperatures [42]. Air temperatures of 37 to $38.4{ }^{\circ} \mathrm{C}$ are common from December to February in the study sites in NE Argentina, which are about $10^{\circ} \mathrm{C}$ higher than the optimum temperature for leaf photosynthesis of some tropical species [43]. An important consequence of heat stress is an inhibition of the photosynthetic apparatus [44]. High temperatures may cause stomatal closure, impair enzyme activity, and decrease in the efficiency of the light harvesting system and will consequently result in low $\mathrm{CO}_{2}$ assimilation and plant growth [44-46]. Many lowland tropical trees have optimum temperatures for leaf photosynthesis at about $27{ }^{\circ} \mathrm{C}$ and tend to remain relative constant when day/night growing temperatures are experimentally changed [47]. Ten degrees centigrade above this optimum temperature, two tropical rainforest species in Costa Rica substantially decrease net $\mathrm{CO}_{2}$ assimilation as well as the quantum yield [43]. Furthermore, $10{ }^{\circ} \mathrm{C}$ increases in leaf temperature result in a two to threefold increase in dark respiration rates that will lower net photosynthetic rates [43]. It is true that dark respiration could acclimate under high temperature conditions in some plant species, implying that respiration rates at a common temperature will decrease during warm months [48]. It is highly unlikely, however, that the acclimation response may compensate for the substantial air temperature increase observed during the hottest months. A regression analysis between air temperature and NDVI for the subtropical forest studied, within the course of each year, showed that monthly NDVI tended to increase to a maximum and then remained constant or decreased with increasing temperatures (results not shown). Therefore, common air temperatures of 37 to $38^{\circ} \mathrm{C}$ in December to February in the study sites probably inhibit photosynthesis, thereby resulting in the small NDVI decrease observed from December to February.

\subsubsection{NDVI in Relation to Leaf Area Index, Chlorophyll Content, and Stem Growth Rates}

The decreased NDVI in the cold season was consistent with the seasonal pattern of LAI. The substantial decrease in LAI is at least partially responsible for the small seasonal decline in NDVI. The LAI estimates by remote sensing were within the LAI range measured in the field. MODIS LAI varied seasonally from 4.7 to 6.4 across native forests and plantations. The field estimates of LAI depicted relatively high values of about 6.7 for native forest stands and for the A. angustifolia tree plantation. The other tree plantations ranged from 3.7 to 4.3. It has been suggested that the MODIS LAI product for conifer forests underestimated the LAI values compared to field measurements [20]. LAI values observed in our study were similar to the average values of LAI in other forest ecosystems. For example, Yang et al. [49] found LAI values for broadleaf forests in North America between 4.5 and 6 through different simulation models with Terra and Aqua MODIS sensors. However values of LAI for needle leaf forests were lower ranging from 2 to 3.5. In boreal deciduous and coniferous forests, LAI values from MODIS were relatively lower (2.2) than field estimates with hemispherical digital photographs (3.0) [21]. LAI values for boreal forests are expected to be substantially lower than LAI in tropical and subtropical forests.

The time series analysis of LAI exhibited more peaks for both the native forests and the tree plantations compared to NDVI time series; however, for the native forest there were only three 
significant peaks corresponding to 12-, 7.2- and 4-month periods. The 12-month cycle that is observed across all LAI time series represents the LAI values that decrease during the cold season occurring only once every year. Similarly to the native forests, the cold season decrease in LAI of the tree plantations could be partially due to leaf dropping or understory vegetation die back.

The negative effects of decreased LAI on cold season NDVI and potential canopy photosynthesis could be in part compensated by increased leaf chlorophyll concentrations in the cold season. Chlorophyll concentrations of leaves tended to be higher in winter in four of the five ecosystems studied. The higher chlorophyll concentrations in the cold season could help the canopy maintain relatively high NDVI values, as high chlorophyll concentration promotes photosynthetic light interception and increases light use efficiency. Therefore, the NDVI values, as a measure of potential forest canopy photosynthetic activity, remain fairly constant throughout the year (the intra-annual coefficient of variation was only $1.9 \%$ ) comparable to high-yield tree plantations. These results partially explain the high NDVI in subtropical forests from NE Argentina, despite lower air temperatures and lower LAI during the cold season.

The high NDVI and potential canopy photosynthesis of the Atlantic subtropical forests and plantations are consistent with the seasonal pattern of stem growth. The trees in plantations exhibited constant stem growth rates, except in August, suggesting that low temperatures are limiting photosynthetic carbon assimilation and tree growth during the cold season. Additionally, the trees in native forests exhibited lower growth rates compared to the trees in the plantations, probably because the native forests are in their later-successional stage and trees were substantially older. The native forests were selectively logged for a few valuable timber species before 1934, and then the area was protected as a National Park. In contrast, the Pinus plantations are relatively young and thus are expected to have high growth rates. In addition, Pinus and Eucalyptus used in plantations have been selected for their high yields and large allocation of biomass to stem growth compared to trees in native forests. Furthermore, management techniques are used in the plantations to maximize tree growth rates such as thinning. The growth rates of the native evergreen trees were lower than for the native deciduous species. The deciduous trees are generally high light-requiring species, while the evergreen trees tend to be more shade tolerant. In August and September, 2012, there was a decrease in stem size, indicating stem shrinkage. Monthly precipitation for August and September, 2012, were 11 and $77 \mathrm{~mm}$, respectively, which was substantially lower than the 13-year averages $(71$ and $161 \mathrm{~mm}$, respectively). During this period, water of the internal stem storages was mainly used to replace evaporative losses when soil water availability was low (unpublished results). A significant positive linear relationship between monthly stem growth increments and NDVI was observed for evergreen and deciduous species. We did not expect a strong correlation between stem growth rates and NDVI because stem growth can have different temporal patterns from canopy photosynthetic activity due to delayed allocation of photosynthates to wood growth. However, the relationship observed between these two variables reinforces the idea that NDVI can be considered a reliable proxy of canopy photosynthesis for these subtropical forests. 


\section{Conclusions}

Our results suggest that the NDVI values, as a measure of potential canopy photosynthetic activity of the Atlantic subtropical forests, remains fairly high throughout the year, comparable to high-yield tree plantations. The NDVI values of the studied subtropical forests and tree plantations are among the highest for forest ecosystems. This high NDVI and potential year-round canopy photosynthesis of the native forests and tree plantations were consistent with stem growth throughout the year. Two NDVI peaks were observed in late summer-early autumn and spring (November) because high and low air temperatures may have small detrimental effects on photosynthetic activity during the warm and cold seasons. The small NDVI decrease in the cold season was consistent with the seasonal decrease in remote sensing and field-measured LAI. The detrimental effects of low temperatures and LAI decline in the cold season could be partially compensated by increased leaf chlorophyll concentrations of evergreen trees and higher incoming solar radiation due to decrease leaf surface area of the deciduous trees, allowing high NDVI values to be maintained throughout the year. High NDVI and potential canopy photosynthesis of the subtropical forest in NE Argentina, similar to the subtropical forests in China, suggests that they can be large carbon sinks owing to year-round carbon sequestration. Thus conservation and restoration of the humid subtropical forests worldwide are of importance for global carbon balance.

\section{Acknowledgments}

We thank Patricio Mac Donagh, Hugo Reis and APN (CIES, DTNEA and park rangers). We also thank the Instituto de Clima y Agua of INTA Castelar for providing satellite images and particularly Patricio Oricchio for his ongoing advice. We are also grateful to the institutions that partially funded this work: ANPCyT through a PITEC project (Consolidación del Aglomerado Productivo Forestal Misiones y Norte de Corrientes) and a PICT 2011-01860, and MAGyP-UCAR (PIA 10101). Field measurements were conducted in tree plantations of Pindó S.A. and Lipsia S.A.

\section{Conflict of interest}

The authors declare no conflict of interest.

\section{References}

1. Tan, Z.H.; Zhang, Y.P.; Liang, N.; Hsia, Y.J.; Zhang, Y.J.; Zhou, G.Y.; Li, Y.L.; Juang, J.Y.; Chu, H.S.; Yan, J.H.; et al. An observational study of the carbon-sink strength of East Asian subtropical evergreen forests. Environ. Res. Lett. 2012, 7, 1-12.

2. Zhang, Y.J.; Yang, Q.Y.; Lee, D.W.; Goldstein, G.; Cao, K.F. Extended leaf senescence promotes carbon gain and nutrient resorption: Importance of maintaining winter photosynthesis in subtropical forests. Oecologia 2013, 173, 721-730.

3. Zhang, Y.J. Water and Carbon Balances of Evergreen and Deciduous Broadleaf Trees from a Subtropical Cloud Forest in Southwest China. Ph.D. Thesis, University of Miami, Coral Gables, FL, USA, 7 May 2012. 
4. Zhang, Y.J.; Cao, K.F.; Goldstein, G. Winter Photosynthesis of Evergreen Broadleaf Trees from a Montane Cloud Forest in Subtropical China. In Photosynthesis Research for Food, Fuel and the Future; Springer Berlin: Heidelberg, Germany, 2013; pp. 812-817.

5. Galindo-Leal, C.; Gusmão Câmara, I. The Status of the Atlantic Forest Hotspot: The Dynamics of Biodiversity Loss; Island Press: Washington, DC, USA, 2003; p. 85.

6. Myers, N.; Mittermeier, R.A.; Mittermeier, C.G.; da Fonseca, G.A.B.; Kent, J. Biodiversity hotspots for conservation priorities. Nature 2000, 403, 853-858.

7. Izquierdo, A.E.; De Angelo, C.D.; Aide, T.M. Thirty years of human demography and land-use change in the Atlantic Forest of Misiones, Argentina: An evaluation of the forest transition model. Ecol. Soc. 2008, 13, 3.

8. Gatti, M.G.; Campanello, P.I.; Montti, L.F.; Goldstein, G. Frost resistance in the tropical palm Euterpe edulis and its pattern of distribution in the Atlantic Forest of Argentina. For. Ecol. Manag. 2008, 256, 633-640.

9. Tucker, C.J. Remote sensing of leaf water content in the near infrared. Remote Sens. Environ. 1980, 10, 23-32.

10. Gower, S.T.; Kucharik, C.J.; Norman, J.M. Direct and indirect estimation of leaf area index, fPAR and net primary production of terrestrial ecosystems. Remote Sens. Environ. 1999, 70, 29-51.

11. Paruelo, J.M.; Oesterheld, M.; Di Bella, C.; Arzadum, M.; Lafountaine, J.; Cahuepé, M.; Rebella, C.M. Estimation of primary production of subhumid rangelands from remote sensing data. Appl. Veg. Sci. 2000, 3, 189-195.

12. Oliveira, T.; Carvalho, L.; Oliveira, L.; Lacerda, W.; Acerbi, F., Jr. NDVI Time Series for Mapping Phonological Variability of Forests Across the Cerrado Biome in Minas Gerais, Brazil. In Phenology and Climate Change; Zhang, X., Ed.; In Tech: Shanghai, China, 2012; pp. 253-272.

13. Tucker, C.J.; van Praet, C.L.; Sharman, M.J.; van Ittersum, G. Satellite remote sensing of total herbaceous biomass production in the Senegalese Sahel. Remote Sens. Environ. 1985, 17, 233-249.

14. Baret, F.; Guyot, G. Potentials and limits of vegetation indices for LAI and APAR assessment. Remote Sens. Environ. 1991, 35, 161-173.

15. Gamon, J.A.; Field, C.B.; Goulden, M.L.; Griffin, K.L.; Hartley, A.E.; Joel, G.; Valentini, R. Relationships between NDVI, canopy structure and photosynthesis in three Californian vegetation types. Ecol. Appl. 1995, 5, 28-41.

16. Huete, A.R.; Liu, H.Q.; Batchily, K.; van Leeuwen, W. A comparison of vegetation indices global set of TM images for EOSMODIS. Remote Sens. Environ. 1997, 59, 440-451.

17. Paruelo, J.M.; Epstein, H.E.; Lauenroth, W.K.; Burke, I.C. ANPP estimates from NDVI for the central grassland region of the US. Ecology 1997, 78, 953-958.

18. Gamon, J.; Field, C.; Goulden, M.; Griffin, K.; Hartley, A.; Joel, G.; Peñuelas, J.; Valentini, R. Relationship between NDVI, canopy structure, and photosynthesis in three Californian vegetation types. Ecol. Appl. 1995. 5, 28-41.

19. Muraoka, H.; Noda, H.; Nagai, S.; Motohka, T.; Saitoh, T.; Nasahara, K.; Saigusa, N. Spectral vegetation indices as the indicator of canopy photosynthetic productivity in a deciduous broadleaf forest. J. Plant Ecol. Adv. Access 2013, 6, 393-407. 
20. De Kauwe, M.G.; Disney, M.I.; Quaife, T.; Lewis, P.; Williams, M. An assessment of the MODIS collection 5 leaf area index product for a region of mixed coniferous forest. Remote Sens. Environ. 2011, 115, 767-780.

21. Rautiainen, M.; Heiskanen, J.; Korhonen, L. Seasonal changes in canopy leaf area index and MODIS vegetation products for a boreal forest site in central Finland. Boreal Environ. Res. 2011, $17,71-84$.

22. Ligier, H.D.; Matteio, H.R.; Polo, H.L.; Rosso, J.R. Provincia de Misiones. In Atlas de suelos de la República Argentina, Volumen II; Centro de Investigaciones de Recursos Naturales, INTA: Buenos Aires, Argentina, 1990; pp. 111-154.

23. Soil Survey Staff. Keys to Soil Taxonomy, SMSS Technical Monograph No. 19, 5th ed.; Pocahontas Press Inc.: Blacksburg, VA, USA, 1992; p. 556.

24. Pinkard, E.A.; Patel, V.; Mohammed, C. Chlorophyll and nitrogen determination for plantation-grown Eucalyptus nitens and E. globulus using a non-destructive meter. For. Ecol. Manag. 2006, 223, 211-217.

25. Coste, S.; Baraloto, C.; Leroy, C.; Marcon, E.; Renaud, A.; Richardson, A.D.; Roggy, J.C.; Schimann, H.; Uddling, J.; Herault, B. Assessing foliar chlorophyll contents with the SPAD-502 chlorophyll meter: A calibration test with thirteen tree species of tropical rainforest in French Guiana. Ann. For. Sci. 2010, 67, 607.

26. Cattelino, P.J.; Becker, C.A.; Fuller, L.G. Construction and installation of manmade dendrometer bands. North. J. Appl. For. 1986, 3, 73-75.

27. Running, S.W.; Justice, C.O.; Salomonson, V.; Hall, D.; Barker, J.; Kaufmann, Y.J.; Strahler, A.H.; Huete, A.R.; Muller, J.P.; Vanderbilt, V.; et al. Terrestrial remote sensing science and algorithms planned for EOS/MODIS. Int. J. Remote Sens. 1994, 15, 3587-3620.

28. Tedrow, L.; Weber, K.T. NDVI Changes Over a Calendar Year in the Rangelands of Southeast Idaho. In Final Report: Assessing Post-Fire Recovery of Sagebrush-Steppe Rangelands in Southeastern Idaho (NNX08AO90G); Weber, K.T., Davis, K., Eds.; Idaho State University: Pocatello, ID, USA, 2011; pp. 105-116.

29. Gessner, U.; Niklaus, M.; Kuenzer, C.; Dech, S. Intercomparison of leaf area index products for a Gradient of sub-humid to arid environments in West Africa. Remote Sens. 2013, 5, 1235-1257.

30. Myneni, R.B.; Hoffman, S.; Knyazikhin, Y.; Privette, J.L.; Glassy, J.; Tian, Y.; Wang, Y.; Song, X.; Zhang, Y.; Smith, G.R. Global products of vegetation leaf area and fraction absorbed PAR from year one of MODIS data. Remote Sen. Environ. 2002, 83, 214-231.

31. Jacquemoud, S.; Verhoef, W.; Baret, F.; Bacour, C.; Zarco-Tejada, P.J.; Asner, G.P.; Francois, C.; Ustin, S.L. PROSPECT+SAIL models: A review of use for vegetation characterization. Remote Sens. Environ. 2009, 113, 556-566.

32. Land Processes Distributed Active Archive Center. Available online: http://pdaac.usgs.gov (accessed on Day September 2013).

33. Bloomfield, P. Fourier Analysis of Time Series: An Introduction, 2nd ed.; Wiley: New York, NY, USA, 1976; p. 257. 
34. Elliott, D.F.; Rao, K.R. Fast Transforms: Algorithms, Analyses, Applications; Academic Press: New York, NY, USA, 1982; p. 448.

35. Wei, W.W. Time Series Analysis: Univariate and Multivariate Methods; Addison-Wesley: New York, NY, USA, 1989; p. 614.

36. Hashemi, S.A.; Chenani, S.K. Investigation of NDVI index in Relation to Chlorophyll Content Change and Phenological Event. In Recent Advances in Environment, Energy Systems and Naval Science, Proceedings of the 4th International Conference on Environment, Barcelona, Spain, 15-17 September 2011; Wseas LLC: City, State Abbr., USA, 2011; pp. 22-28.

37. Huete, A.; Didan, K.; Miura, T.; Rodriguez, E.P.; Gao, X.; Ferreira, L.G. Overview of the radiometric and biophysical performance of the MODIS vegetation indices. Remote Sens. Environ. 2002, 83, 195-213.

38. Holaday, A.S.; Martindale, W.; Aired, R.; Brooks, A.; Leegood, R.C. Changes in activities of enzymes of carbon metabolism in leaves during exposure to low temperature. Plant Physiol. 1992, 98, 1105-1114.

39. Campanello, P.I.; Gatti, M.G.; Goldstein, G. Coordination between water-transport efficiency and photosynthetic capacity in canopy tree species at different growth irradiances. Tree Physiol. 2008, 28, 85-94.

40. Zhang, Y.J. Harvard University, Cambridge, MA, USA. Carbon balance of an Asian subtropical cloud forest. Unpublished work, 2014.

41. Soudani, K.; Hmimina, G.; Delpierre, N.; Pontailler, J.Y.; Aubinet, M.; Bonal, D.; Caquet, B.; de Grandcourt, A.; Burban, B.; Flechard, C.; et al. Ground-Based Network of NDVI measurements for tracking temporal dynamics of canopy structure and vegetation phenology in different biomes. Remote Sens. Environ. 2012, 123, 234-245.

42. Kurek, I.; Chang, T.K.; Bertain, S.M.; Madrigal, A.; Liu, L.; Lassner, M.W.; Zhu, G. Enhanced thermostability of Arabidopsis Rubisco activase improves photosynthesis and growth rates under moderate heat stress. Plant Cell 2007, 19, 3230-3241.

43. Vargas, G.G.; Cordero, S.R.A. Photosynthetic responses to temperature of two tropical rainforest tree species from Costa Rica. Trees 2013, 27, 1261-1270.

44. Sharkey, T.D. Effects of moderate heat stress on photosynthesis: Importance of thylakoid reactions, rubisco deactivation, reactive oxygen species, and thermotolerance provided by isoprene. Plant Cell Environ. 2005, 28, 269-277.

45. Lloyd, J.; Farquhar, G.D. Effects of rising temperatures and $\mathrm{CO}_{2}$ on the physiology of tropical forest trees. Philos. Trans. R. Soc. Ser. B 2008, 363, 1811-1817.

46. Berry, J.A.; Bjorkman, O. Photosynthetic response and adaptation to temperature in higher plants. Ann. Rev. Plant Physiol. 1980, 31, 491-543.

47. Goldstein, G.; Meinzer, F.; Rada, F. Environmental biology of a tropical treeline species, Polylepis sericea. In Tropical Alpine Environments: Plants Form and Function; Rundel, P.W., Smith, A.P., Meinzer, F.C., Eds.; Cambridge University Press: Cambridge, UK, 1994; pp. 129-149.

48. Larigauderie, A.; Korner, C. Acclimation to leaf dark respiration to temperature in Alpine and lowland plant species. J. Botan. 1995, 76, 245-252. 
49. Yang, W.; Shabanov, N.V.; Huang, D.; Wang, W.; Dickinson, R.E.; Nemani, R.R.; Knyazikhin, Y.; Myneni, R.B. Analysis of leaf area index products from combination of MODIS Terra and Aqua data. Remote Sens. Environ. 2006, 104, 297-312.

(C) 2014 by the authors; licensee MDPI, Basel, Switzerland. This article is an open access article distributed under the terms and conditions of the Creative Commons Attribution license (http://creativecommons.org/licenses/by/3.0/). 